\title{
THE NOVA SCOTIAN INSTITUTE OF SCIENCE STUDENT SCIENCE AWARDS 2005
}

\section{Purpose}

To provide an opportunity for students to have their work recognized by a scientific society and to have it considered for publication in a peer-reviewed scientific journal.

\section{Eligibility}

The competition is open to any student currently enrolled in a degree program at a recognized educational institution.

\section{Categories and prizes}

\section{Undergraduate student}

Three broad categories for competition:
Environmental Sciences
e.g. terrestrial ecology, marine biology atmospheric sciences, earth sciences etc.
Life Sciences e.g. animal and plant cell biology, medical sciences, biochemistry, physiology etc.
Physical Sciences e.g. physics, chemistry, engineering,
mathematics, computer science etc.

Three undergraduate prizes are available in each of these three categories:

1st prize

2nd prize

3rd prize
$\$ 200$ plus one year's membership to NSIS $\$ 100$ plus one year's membership to NSIS one year's membership to NSIS

\section{Graduate Student}

Any discipline

Single prize of $\$ 500$ plus one year's membership to NSIS

\section{Scientific Writing}

For an article written by a student in a non-scientific discipline Subject must be relevant to science in Nova Scotia

Single prize of $\$ 200$ plus one year's membership to NSIS 


\section{STUDENT SCIENCE AWARDS 2005}

The Graduate Student Prize was awarded to:

David M. Conrad

PhD Student Microbiology and Immunology

Dalhousie University

for

"Clear as mud: the type I/type II model for death

receptor-induced apoptosis"

The Graduate Student Special Prize for High Merit was awarded to:

Jane E. Tougas

Masters Student Computer Science

Dalhousie University

for

"A comparison of methods for modifying the partial singular value decomposition in latent semantic indexing"

The Undergraduate Student Prize in the Life Sciences

was awarded to:

Mark Wall

BSc Student Chemistry

University College of Cape Breton

for

"Growth and phenyalanine ammonia lyase activity of Rhodotorula glutinis: optimization of conditions for the synthesis of L-phenylalanine"

The Undergraduate Student Prize in the Physical Sciences was awarded to: Jackie Glister

BSc Student Physics

Saint Mary's University

for

"Design study of novel light geometry for scintillation counters"

The Scientific Writing Prize was awarded to: Jennifer Paterson

School of Journalism

University of King's College

for

"Rational drug design: a window into the ambitious quest of a

neurologist and chemist" 